\title{
The Influence of Budget Transparency on Quality of Governance
}

\author{
Bassam A. Albassam, Ph.D \\ Institute of Public Administration, Riyadh, Saudi Arabia, P.O.Box 2015, Riyadh, 11141, Saudi Arabia \\ Email:bassamb@ipa.edu.sa
}

\section{Doi:10.5901/mjss.2016.v7n1p227}

\begin{abstract}
Public budget is the engine that drives any economy; thus, budget transparency contributes to shaping the political process and government performance. The current study examines the relationship between budget transparency (measured by Open Budget Index (OBI)) and governance quality (measured by Worldwide Governance Indicators (WGI)). The study covers four years - 2006, 2008, 2010, and 2012 - where OBI data are available. Furthermore, the role of the human development level of nations in shaping this relationship is tested. While the result of the analysis shows a significant relationship between budget transparency and governance quality, which is inconsistent with the literature, the findings indicate minimal influence of the human development level of nations on this relationship. This result confirms the influence of budget transparency in the adoption of good governance practices by governments and increased quality of governance. Future research can examine the relationship between human development and quality of governance in the process of understanding factors that contribute in enhancing the governing process.
\end{abstract}

Keywords: budget transparency, governance quality, human development

\section{Introduction}

Aaron Wildavsky (1961), in his masterpiece Political Implications of Budgetary Reform, stated "[T]he budget is the lifeblood of the government, the financial reflection of what the government does or intends to do" (p. 184). The budgetary system and the public budget process have impacts on the way government operates. Thus, the cornerstone of developing financial systems in countries starts with the development of the public budget. Also, the public budget contributes to human development, economic growth, and governing. Therefore, international organizations, donors, and civil society organizations advocate budget transparency and accountability toward better governance.

Conversely, good governance has been introduced as a tool to work toward better service for citizens, political stability, and government effectiveness. Furthermore, good governance is connected to fighting corruption and holding bureaucrats and politicians accountable for their actions. Consequently, good governance practices by governments are a prerequisite of financial and nonfinancial aids from donors to countries in need of assistance.

The main theme of the current article is to study the influence of budget transparency on good governance. The open budget index (OBI) as a measure of budget transparency, as well as the worldwide governance indicators (WGI) (Voice and Accountability (VA), Political Stability and Absence of Violence (PS), Government Effectiveness (GE), Regulatory Quality (RQ), Rule of Law (RL), and Control of Corruption (CC)) as a measure of good governance, have been used in studying the relationship between budget transparency and good governance. The study covers 2006, 2008, 2010, and 2012, where OBI data are available.

In addition, the current study will explore the influence of human development in shaping the relationship between good governance and budget transparency. The human development index (HDI), which will be used in the current study as a measure of human development, classifies countries into four groups (very high development, high development, medium development, and low development). The three dimensions used in constructing HDI are health, education, and living standards.

Where most prior studies on this subject have concentrated on one aspect of governance, the current article is exploring the influence of budget transparency on all six indicators of good governance, which will enhance the knowledge regarding the relationship between budget transparency and quality of governance. Also, studying the relationship between budget transparency and governance on a global scale (compared to the regional or country level) allows for studying the relationship in a variety of political and governmental systems. In addition, the current study will explore the influence of human development on the relationship between good governance and budget transparency, thus filling the research gap in exploring this issue. 
While the result of the analysis shows a significant relationship between budget transparency and quality of governance, the analysis concludes that the human development level of nations has a minimal influence in shaping the relationship. This result confirms the influence of budget transparency on governments' adoption of good governance practices and increasing quality of governance. In contrast, although human development significantly moderates the relationship between budget transparency and regulatory quality and between budget transparency and government effectiveness, it did not moderate any other relationships.

\section{Budget Transparency}

The theme of transparency has been addressed through numerous studies in many fields (e.g., political, economic, and social sciences). Kosack and Fung (2014) argue that the notion of transparency has been adopted by governments and international organizations based on the promise that "disclosure of information about government institutions, policies, and programs empowers citizens to hold officials responsible for their spending and performance, thereby reducing corruption and mismanagement of public resources and leading, eventually, to more accountable, responsive, and effective governance" (p. 65). Thus, transparency is argued to be an important tool for better governing.

Over the years, many definitions of budget transparency have been introduced. Premchand (1993) defines budget transparency as "the availability of information to the public on the transactions of the government and the transparency of decision-making processes" (p. 17). The Organization for Economic Co-operation and Development (OECD) defines budget transparency as "the full disclosure of all relevant fiscal information in a timely and systematic manner" (OECD 2002, p. 1). The definition of open budget initiative that will be utilized in the current paper explicates details in defining budget transparency: "transparency means all of a country's people can access information on how much is allocated to different types of spending, what revenues are collected, and how international donor assistance and other public resources are used" (IBP, 2010, par. 4).

Accordingly, budget transparency movements are motivated by the assumption that "enhancing transparency and accountability in the budget process will lead to improved democratic and developmental outcomes" (Carlitz, 2013, p.s53). In contrast, the length and complexity of the public budget makes it difficult for the average citizen to understand; thus, it has been argued that too much budget transparency can do more harm than good (Persson, Rothstein \& Teorell, 2010; Kolstad \& Wiig, 2009). On the contrary, Carlitz (2013) stated that "access to budget information and budget processes clearly has the potential to empower citizens and make their governments respond in ways that may improve their lives" (p. s63).

\section{Good Governance}

Good governance is the standard used to determine the quality of governing by countries and international institutions providing political, administrative, and financial support and advice to other countries. Also, international financial institutions (e.g., the IMF and the World Bank) and donor countries (e.g., the United States and the United Kingdom), use good governance as a standard to evaluate countries' affairs and systems. This evaluation contributes, in part, to the decision of whether or not to provide aid to those countries (Mimicopoulos, Kyj, and Sormani, 2007; Santiso, 2001).

Good governance is defined as "the ability of government to develop an efficient, effective and accountable public management process that is open to citizen participation and that strengthens rather than weakens a democratic system of government" (Riddell, 2007, p. 374). In addition, international organizations deem that good governance is a condition for economic development and efforts to fight corruption. The United Nations has introduced eight major characteristics of good governance that define and articulate good governance practices by governments: "[good governance is] participatory, consensus oriented, accountable, transparent, responsive, effective and efficient, equitable and inclusive, and follows the rule of law" (UNESCAP, 2009, p. 1). In addition, good governance is characterized by respecting human rights and adopting democratic principles by governments (e.g., citizen participation and transparency) in decisionmaking processes (Denhardt \& Denhardt, 2007; Kosack \& Fung, 2014).

\section{Transparency and Good Governance: Previous Studies}

Many studies have been conducted to examine the relationships between budget transparency and government's performance and activities; budget transparency and countries' development (Gaventa \& McGee 2013); budget transparency, fiscal performance, and political turnout (Benito \& Bastida, 2009; Stiglitz, 2002); and transparency and good governance (Acosta, 2013; Kolstad \& Wiig, 2009). The positive influence of government work's transparency on a 
country's development and quality of governance is a common finding among most of these studies.

Benito and Bastida (2007) study the relationship between budget transparency on one side and economic development and fighting corruption on the other. Even though every country has a different culture and political system, which might affect the way each country applies public budget transparency standards, the authors find a strong relationship among budget transparency, economic development, and efforts to fight corruption in all countries included in the research. Additionally, the study concludes that budget transparency increases a government's accountability and improves the decision-making process. In addition, Benito and Bastida (2009) study the relationship between budget transparency based on the availability of information from governments and citizen participation in the political process. After admitting the difficulty of measuring political participation by using one only aspect of it (voting), the study nonetheless finds a positive relationship among budget transparency, fiscal performance, and political turnout.

Renzio, Gomez, and Sheppard (2009) study the relationship between budget transparency and human development in resource-dependent countries - that is, countries that depend on natural resources (e.g., oil or minerals) as their main source of income. Using open budget initiative data collected in 2006, they compare these scores with the UN Human Development Index (HDI) for each country. While they find that resource-dependent countries suffer from a lack of budget transparency, Renzio et al. (2009) find no clear relationship between budget transparency and a country's level of development.

In contrast, Zucolotto and Teixeira (2014) study the influence of budget transparency on corruption, accountability, quality of legislature institutions, and democracy in countries. The study concludes that "countries that are more transparent have more and better accountability mechanisms and, consequently, a greater level of democracy and less corruption, all of which points to the importance of transparency in the process of democratic consolidation" (Zucolotto \& Teixeira, 2014, p. 96).

In summary, while budget transparency has been connected to good governance practices by governments, information access by the public has not played the role of an end in itself but rather a tool toward better governance. Thus, to have an effective and efficient system and to benefit from budget transparency, the public (e.g., citizens and nonprofit organizations) must have the capability to monitor authorities and hold them accountable for their actions. In their study of the effect of budget transparency on the performance of resource-rich countries, Kolstad and Wiig (2009) argue that budget transparency in and of itself cannot be the only solution to reduce corruption and maintain sustainable development unless combined with improved quality of institutions and policies (financial and otherwise), citizen empowerment, and human development level. Similarly, Lindstedt and Naurin (2010) stated, "Reforms focusing on increasing transparency should be accompanied by measures for strengthening citizens' capacity to act upon the available information if we are to see positive effects on corruption" (p. 301).

\section{Human Development}

Human development has been associated with quality of governance (Grindle, 2007; Sagar \& Najam, 1998), economic growth (Adams \& Mengistu, 2008; Smith, 2007), and sustainable development (Alkire, 2010; Ndulu \& O'Connell, 1999). In addition, human development shares some principals with good governance practices by governments, such as supporting free speech, upholding human rights, and improving public services' quality (Grindle, 2007; Sagar \& Najam, 1998). Therefore, Pradhan and Sanyal (2011) argue that good governance practices (e.g., rule of law and transparency) are conditions for high levels of education and health systems; thus, high quality of governance results in more efficient and effective government work that leads to high levels of human and economic development.

Similarly, Alkire (2010) thinks that human development (e.g., high-quality education and health systems) supports the productivity of an economy by providing healthy and highly trained individuals. To this end, human development requires both economic growth and good governance practices by governments. According to The United Nations Development Program (UNDP) (2000), "resources generated by economic growth have financed human development and created employment while human development has contributed to economic growth" (p. 7). Consequently, governments need to adopt balanced development of the governance process, economic and human development in order to enhance the well-being of citizens and increase the effectiveness of the government's work.

\section{Methodology and Data Sources}

Although many studies have addressed governance throughout history, little has been said regarding the relationship between budget transparency and governance. The current paper attempts to fill this gap by studying the relationship between budget transparencies from 2006 to 2012. Thus, the first research question is: Is there a relationship between 
budget transparency (independent variable) and quality of governance (dependent variable)? Furthermore, the current study will explore whether the relationships between budget transparency and each governance indicator vary based on a country's level of development. Thus, the second research question is: Does the relationship between budget transparency and quality of governance vary from country to country based on each country's level of development?

\subsection{Measuring Budget Transparency}

Many indices and guidelines have been introduced in an effort to measure and evaluate the application of budget transparency by governments (e.g., open budget index (OBI), best practices for budget transparency by the Organization for Economic Co-operation and Development (OECD), and guidelines for public expenditure management by the International Monetary Fund (IMF)). Although it is based on data collected through surveys sent to institutions and civil society organizations - which raises some concerns regarding the accuracy of the results, since most of the data collection is based on the subjectivity of the participants rather than fact-based analysis (de Renzio et al., 2005; Hameed, 2011) - the open budget index (OBI) is nonetheless considered by many scientists and organizations to be the most reliable and credible tool available for measuring the application of budget transparency by governments (Carlitz, 2013; Santiso, 2006; Wehner \& de Renzio, 2013). OBI "assesses whether governments provide their citizens with timely, comprehensive, and useful budget information; whether oversight institutions, including the legislature and external auditors, are effectively performing their role; and whether the public has opportunities to participate in the budget process" (Masud, p. 43).

$\mathrm{OBI}$ is a product of the open budget initiative, which is part of the International Budget Partnership's (IBP) program, which is founded by the Center on Budget and Policy Priorities. The first index of OBI was issued 2006, and it has been issued every two years since. OBI collected data from 100 countries in 2012 (International Budget Partnership, 2012). In the current paper, the open budget index is used as a measure of budget transparency. According to International Budget Partnership (2012):

The Open Budget Index (OBI) assigns each country a score from 0 to 100 based on the simple average of the numerical value of each of the responses to the 95 questions in the questionnaire that assess the public availability of budget information. A country's OBI score reflects the timeliness and comprehensiveness of publicly available budget information in the eight key budget documents (p. 45).

\subsection{Measuring Governance}

While there are many governance indices, most specialize in measuring certain aspects of the governing process, while few attempt to comprehensively cover all aspects of governance (Mimicopoulos et al., 2007; Thomas, 2008). The World Bank Group's set of worldwide governance indicators (WGI) is considered by many scholars to be "the most comprehensive publicly available set of governance indicators" (Arndt \& Oman, 2006, p. 28).

The current paper will use the worldwide governance indicators (WGIs) as a measure of the quality of governance for several reasons. The WGI includes six indicators, each of which measures one aspect of the governing process. Unlike other indices, the WGI contains an indicator for each aspect of the governing process, affording researchers and policy-makers a better understanding of the political process (de Ferranti et al., 2009; Langbein \& Knack, 2010). Accordingly, in the current research, each indicator will be used as a separate, unique variable in order to reach a better understanding of the relationship between each aspect of the governance process and budget transparency.

In addition, 31 sources of data were used to construct the WGI indicators, thus enriching their quality (Kaufmann et al., 2010, 2009). The WGI, which used more than 441 variables in formulating and measuring the six indicators of governance, covers more than 213 countries and territories, making this the only set of indicators to cover all member states of the United Nations (Arndt \& Oman, 2006). The WGI has been an annual indicator since 2004; however, it was biannual from 1996-2003. Accordingly, a scale of low to high quality of governance $(-2.5$ to +2.5$)$, will be adopted in the current paper. Six dimensions are used in measuring the level and quality of governance as part of the Worldwide Governance Indicators (WGI): 1) Voice and Accountability (VA), 2) Political Stability and Absence of Violence (PS), 3) Government Effectiveness (GE), 4) Regulatory Quality (RQ), 5) Rule of Law (RL), and 6) Control of Corruption (CC) (Kaufmann et al., 2009). 


\subsection{Measuring Human Development}

Many indices and reports have been issued for measuring and evaluating countries' human development level, including the human development index (HDI), human rights index (HRI), and human development reports (HDRs) (McGillivray, 1991; Ranis et al., 2006; Streeten, 1994). HDI has been adopted in the current study because it has been recognized as a well-designed index that captures and measures the majority of human development aspects in a credible and valid way (Haq, 1995; Noorbakhsh, 1998; Ranis et al., 2006).

$\mathrm{HDI}$ is a product of the United Nations Development Program (UNDP) and has been published annually since 1990. HDI is an index that ranks countries based on their human development level relative to other countries. Three dimensions - adult literacy, life expectancy at birth, and standard of living - are used in calculating HDI (UNDP, 2010). According to UNDP (2010), gross national income (GNI) is used to measure the standard of living, life expectancy at birth is used to measure level of life expectancy at birth, and mean years of schooling and expected years of schooling are used to measure level of adult literacy. For every human development component, there is a mathematical formula, and there is an aggregate formula that includes all three formulas to construct HDI (UNDP, 2010). HDI can range from 1.00.0 , where scores of the final formula divides countries as follows: 1.0-0.79 (very high development), 0.78-0.698 (high development), 0.69-0.52 (medium development), and 0.51-0.28 (low development) (UNDP, 2010). For the current paper, the 2006, 2008, 2010, and 2012 issues of HDI will be used.

\section{The Relationship between Budget Transparency and Good Governance}

The first research question sought to determine whether there was a relationship between budget transparency (as measured by the open budget index) and good governance (as measured by Voice and Accountability, Political Stability, Government Effectiveness, Regulatory Quality, Rule of Law, and Control of Corruption). Since all the variables were measured using an interval scale, correlation procedures were conducted. As most of the variables were highly skewed and not distributed normally, non-parametric Kendall-Tau correlation tests were utilized.

\subsection{Budget Transparency and Good Governance in 2006}

The findings in Table 1 reveal that the Open Budget Index (OBI) was positively associated with the six indicators of good governance in 2006. Therefore, increased levels of budget transparency were significantly associated with increased levels of Voice and Accountability (VA), Political Stability (PS), Government Effectiveness (GE), Regulatory Quality (RQ), Rule of Law (RL), and Control of Corruption (CC).

Table 1: Kendall Tau Correlations between Budget Transparency and Good Governance in $2006(\mathrm{~N}=98)$

\begin{tabular}{lcccccc}
\hline Variables & 1 & 2 & 3 & 4 & 5 & 6 \\
\hline Open budget index & & & & & & \\
Control of corruption & $.44^{\star \star \star}$ & & & & & \\
Government effectiveness & $.47^{\star \star \star}$ & $.71^{\star \star *}$ & & & & \\
Political stability & $.23^{\star \star \star}$ & $.48^{\star \star \star}$ & $.41^{\star \star \star}$ & & & \\
Rule of law & $.42^{\star \star \star}$ & $.77^{\star \star \star}$ & $.75^{\star \star \star}$ & $.49^{\star \star \star}$ & & \\
Regulatory quality & $.51^{\star \star \star}$ & $.69^{\star \star \star}$ & $.77^{\star \star \star}$ & $.41^{\star \star \star}$ & $.70^{\star \star \star}$ & \\
Voice and accountability & $.56^{\star \star \star}$ & $.56^{\star \star \star}$ & $.51^{\star \star \star}$ & $.46^{\star \star \star}$ & $.53^{\star \star \star}$ & $.55^{\star \star \star}$ \\
\hline${ }^{*} p<.05 .{ }^{* \star} p<.01 .{ }^{* \star \star} p<.001$. & & & & & &
\end{tabular}

\subsection{Budget Transparency and Good Governance in 2008}

The findings in Table 2 show that the OBI was positively associated with the six indicators of good governance in 2008. Therefore, increased levels of budget transparency were significantly associated with increased levels of VA, PS, GE, $\mathrm{RQ}$, RL, and CC. 
Table 2: Kendall Tau Correlations between Budget Transparency and Good Governance in $2008(N=91)$

\begin{tabular}{|c|c|c|c|c|c|c|}
\hline Variables & 1 & 2 & 3 & 4 & 5 & 6 \\
\hline \multicolumn{7}{|l|}{ Open budget index } \\
\hline Control of corruption & $.42^{\star \star \star}$ & & & & & \\
\hline Government effectiveness & $.41^{\star \star \star}$ & $.58^{\star \star \star}$ & & & & \\
\hline Political stability & $.26^{* \star \star}$ & $.33^{\star \star *}$ & $.29 * \star \star$ & & & \\
\hline Rule of law & $.37^{\star \star \star}$ & 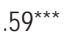 & $.54^{\star \star *}$ & $37^{\star \star \star}$ & & \\
\hline Regulatory quality & $.49^{* \star *}$ & $.58^{\star \star \star}$ & $.54^{\star \star \star}$ & $.37^{\star \star \star}$ & $.57^{\star \star \star}$ & \\
\hline Voice and accountability & $.51^{* \star \star}$ & $.40^{\star \star \star}$ & $.34^{\star \star *}$ & $.28^{\star \star *}$ & $.38^{\star * *}$ & $.39 * \star \star$ \\
\hline
\end{tabular}

\subsection{Budget Transparency and Good Governance in 2010}

As shown in Table 3, the OBI was positively associated with five of the indicators of good governance in 2010. Increased levels of budget transparency were significantly associated with increased levels of VA, GE, RQ, RL, and CC but not PS.

Table 3: Kendall Tau Correlations between Budget Transparency and Good Governance in $2010(N=82)$

\begin{tabular}{|c|c|c|c|c|c|c|}
\hline Variables & 1 & 2 & 3 & 4 & 5 & 6 \\
\hline \multicolumn{7}{|l|}{ Open budget index } \\
\hline Control of corruption & $.32^{\star \star \star}$ & & & & & \\
\hline Government effectiveness & $.35^{\star \star \star}$ & $.51^{* \star *}$ & & & & \\
\hline Political stability & .14 & $.30^{\star \star \star}$ & $.27^{\star \star \star}$ & & & \\
\hline Rule of law & $.30^{\star \star \star}$ & $.59^{\star \star \star}$ & $.60^{\star \star \star}$ & $.35^{\star \star \star}$ & & \\
\hline Regulatory quality & $.39 * \star \star$ & $.45^{\star \star \star}$ & $.59^{\star \star \star}$ & $.34^{* \star *}$ & $.56^{\star \star \star}$ & \\
\hline Voice and accountability & $.46^{\star \star \star}$ & $.36^{\star \star \star}$ & $.37^{\star \star \star}$ & $.31^{\star \star *}$ & $.35^{\star \star \star}$ & $.42^{\star \star \star}$ \\
\hline
\end{tabular}

\subsection{Budget Transparency and Good Governance in 2012}

As shown in Table 4, the OBI was positively associated with five of the indicators of good governance in 2012. Once again, increased levels of budget transparency were significantly associated with increased levels of $V A, G E, R Q, R L$, and CC but not PS.

Table 4: Kendall Tau Correlations between Budget Transparency and Good Governance in 2012 ( $N=57)$

\begin{tabular}{|c|c|c|c|c|c|c|}
\hline Variables & 1 & 2 & 3 & 4 & 5 & 6 \\
\hline \multicolumn{7}{|l|}{ Open budget index } \\
\hline Control of corruption & $.30^{\star * *}$ & & & & & \\
\hline Government effectiveness & $.46^{\star \star *}$ & $.48^{\star \star \star}$ & & & & \\
\hline Political stability & .14 & $.25^{\star * *}$ & $.25^{\star \star *}$ & & & \\
\hline Rule of law & $.40^{\star \star \star}$ & $.63^{\star \star \star}$ & $.58^{\star \star \star}$ & $.32^{* * \star}$ & & \\
\hline Regulatory quality & $.48^{\star \star \star}$ & $.45^{\star \star \star}$ & $.53^{\star \star \star}$ & $.32^{2 * \star}$ & $.55^{\star \star \star}$ & \\
\hline Voice and accountability & $.43^{\star \star \star}$ & $.34^{\star \star \star}$ & $.41^{\star \star *}$ & 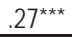 & $.41^{\star \star \star}$ & $.42^{\star \star \star}$ \\
\hline
\end{tabular}

\section{The Moderating Effect of Human Development on the Relationship between Budget Transparency and Good Governance}

The second research question sought to determine whether the relationship between budget transparency (as measured by the $\mathrm{OBI}$ ) and good governance (as measured by VA, PS, GE, RQ, RL, and CC) varied across nations' levels of human development. The independent variable, budget transparency, was transformed into a binary variable, with the top 50 countries categorized into the highly transparent group and the bottom 50 countries assigned to the less transparent group. The moderator, human development, was transformed from a four-category variable into a two-category variable with the Very High and High categories collapsed into a single group and the Medium and Low categories collapsed into 
another group. Because the indicators of good governance were highly skewed (and transformations did not correct for skewness), the six indicators were coded into binary variables based on their medians. Since the dependent variables were binary, logistic regression procedures were conducted. The product of the independent and moderator variables, the interaction term, was evaluated at an alpha of .05.

\subsection{Results for 2006}

Control of corruption. The findings in Table 5 indicate that human development did not moderate the relationship between budget transparency and CC scores in 2006, B $=.07, p=.949$. Rather, human development had a main effect on CC scores, $B=-2.16, p=.001$. In comparison to countries that were highly transparent, the likelihood that countries that were not as transparent would have higher CC scores dropped by .12.

Table 5: Logistic Regression Results for Good Governance in 2006 ( $N=89$ )

\begin{tabular}{|c|c|c|c|c|}
\hline \multirow{2}{*}{\multicolumn{5}{|c|}{$\begin{array}{l}\text { Variables } \\
\text { Control of corruption }\end{array}$}} \\
\hline & & & & \\
\hline High vs. low human development (HD) & -2.16 & \multirow{3}{*}{$\star \star \star *$} & 0.54 & 0.12 \\
\hline High vs. low budget transparency (BT) & -0.78 & & 0.54 & 0.46 \\
\hline $\mathrm{HD} \times \mathrm{BT}$ & 0.07 & & 1.08 & 1.07 \\
\hline \multicolumn{5}{|l|}{ Government effectiveness } \\
\hline High vs. low human development (HD) & -2.90 & \multirow{4}{*}{ 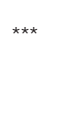 } & 0.67 & 0.06 \\
\hline High vs. low budget transparency (BT) & -0.12 & & 0.67 & 0.89 \\
\hline $\mathrm{HD} \times \mathrm{BT}$ & -1.78 & & 1.35 & 0.17 \\
\hline \multicolumn{4}{|l|}{ Political stability } & \\
\hline High vs. low human development (HD) & -0.85 & & 0.50 & 0.43 \\
\hline High vs. low budget transparency (BT) & -0.06 & & 0.50 & 0.95 \\
\hline $\mathrm{HD} \times \mathrm{BT}$ & -0.64 & & 0.99 & 0.53 \\
\hline \multicolumn{5}{|l|}{ Rule of law } \\
\hline High vs. low human development (HD) & -1.58 & \multirow{3}{*}{ 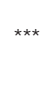 } & 0.52 & 0.21 \\
\hline High vs. low budget transparency (BT) & -0.60 & & 0.52 & 0.55 \\
\hline $\mathrm{HD} \times \mathrm{BT}$ & -0.63 & & 1.03 & 0.53 \\
\hline \multicolumn{5}{|l|}{ Regulatory quality } \\
\hline High vs. low human development (HD) & -2.99 & \multirow{2}{*}{ 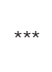 } & 0.71 & 0.05 \\
\hline High vs. low budget transparency (BT) & -0.81 & & 0.71 & 0.44 \\
\hline $\mathrm{HD} \times \mathrm{BT}$ & -3.16 & * & 1.43 & 0.04 \\
\hline \multicolumn{5}{|l|}{ Voice and accountability } \\
\hline High vs. low human development (HD) & -0.50 & \multirow{3}{*}{ *** } & 0.55 & 0.61 \\
\hline High vs. low budget transparency (BT) & -1.85 & & 0.55 & 0.16 \\
\hline $\mathrm{HD} \times \mathrm{BT}$ & 1.09 & & 1.10 & 2.98 \\
\hline
\end{tabular}
${ }^{*} p<.05 .{ }^{* *} p<.01 .{ }^{* * *} p<.001$.

Government effectiveness. Likewise, human development did not moderate the relationship between budget transparency and GE scores, B $=-1.78, p=.187$, but it did have a main effect on GE scores, $B=-2.90, p=.001$. In comparison to countries that were highly transparent, the likelihood that countries that were not as transparent would have higher GE scores dropped by .06 .

Political stability. Human development did not moderate the relationship between budget transparency and PS scores, $B=-.64, p=.520$, nor did it have a main effect on PS scores, $B=-.85, p=.088$.

Rule of law. Human development did not moderate the relationship between budget transparency and RL scores, $\mathrm{B}=-.63, p=.542$, but it did have a main effect on RL scores, $\mathrm{B}=-1.58, p=.002$. In comparison to countries that were highly transparent, the likelihood that countries that were not as transparent would have higher PS scores dropped by .21 .

Regulatory quality. Human development significantly moderated the relationship between budget transparency and $\mathrm{RQ}$ scores, $\mathrm{B}=-3.16, p=.027$. Post-hoc procedures reveal that within countries scoring high on human development, there was no relationship between budget transparency and $\mathrm{RQ}$ scores, $\mathrm{B}=.77, p=.502$; however, within countries scoring lower on human development, there was a relationship between budget transparency and RQ scores, $B=-2.39$, $p=.003$. In particular, in comparison to countries that were highly transparent, the likelihood that countries that were not 
as transparent would have higher RQ scores dropped by .09.

Voice and accountability. Human development did not moderate the relationship between budget transparency and VA scores, $B=1.09, p=.322$, nor did it have a main effect on VA scores, $B=-.50, p=.367$.

\subsection{Results for 2008}

Control of corruption. As shown in Table 6 , human development did not moderate the relationship between budget transparency and CC scores in 2008, B =1.00, $p=.340$. Rather, human development had a main effect on CC scores, $\mathrm{B}$ $=-.25, p=.017$. In comparison to countries that were highly transparent, the likelihood that countries that were not as transparent would have higher CC scores dropped by 29 .

Government effectiveness. Similarly, human development did not moderate the relationship between budget transparency and GE scores, $B=-.05, p=.963$, but it did have a main effect on GE scores, $B=-1.77, p=.001$. In comparison to countries that were highly transparent, the likelihood that countries that were not as transparent would have higher GE scores dropped by .17.

Political stability. Human development also did not moderate the relationship between budget transparency and PS scores, $B=1.46, p=.141$, nor did it have a main effect on PS scores, $B=-.57, p=.253$.

Table 6: Logistic Regression Results for Good Governance in 2008 ( $N=82)$

\begin{tabular}{|c|c|c|c|c|}
\hline \multirow{2}{*}{$\begin{array}{l}\text { Variables } \\
\text { Control of corruption }\end{array}$} & \multicolumn{2}{|c|}{$\mathrm{B}$} & \multirow[t]{2}{*}{ SE } & \multirow[t]{2}{*}{ OR } \\
\hline & & & & \\
\hline High vs. low human development (HD) & -1.25 & * & 0.52 & 0.29 \\
\hline High vs. low budget transparency (BT) & -1.29 & * & 0.52 & 0.27 \\
\hline $\mathrm{HD} \times \mathrm{BT}$ & 1.00 & & 1.04 & 2.71 \\
\hline \multicolumn{5}{|l|}{ Government effectiveness } \\
\hline High vs. low human development (HD) & -1.77 & $\star \star \star * t$ & 0.53 & 0.17 \\
\hline High vs. low budget transparency (BT) & -1.01 & 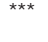 & 0.53 & 0.37 \\
\hline $\mathrm{HD} \times \mathrm{BT}$ & -0.05 & & 1.06 & 0.95 \\
\hline \multicolumn{5}{|l|}{ Political stability } \\
\hline High vs. low human development (HD) & -0.57 & & 0.50 & 0.57 \\
\hline High vs. low budget transparency (BT) & -0.37 & & 0.50 & 0.69 \\
\hline $\mathrm{HD} \times \mathrm{BT}$ & 1.46 & & 0.99 & 4.32 \\
\hline \multicolumn{5}{|l|}{ Rule of law } \\
\hline High vs. low human development (HD) & -0.89 & & 0.50 & 0.41 \\
\hline High vs. low budget transparency (BT) & -0.53 & & 0.50 & 0.59 \\
\hline $\mathrm{HD} \times \mathrm{BT}$ & 0.63 & & 0.99 & 1.88 \\
\hline \multicolumn{5}{|l|}{ Regulatory quality } \\
\hline High vs. low human development (HD) & -2.40 & & 0.58 & 0.09 \\
\hline High vs. low budget transparency (BT) & -1.20 & *夫 & 0.58 & 0.30 \\
\hline HD x BT & -0.87 & & 1.16 & 0.42 \\
\hline \multicolumn{5}{|l|}{ Voice and accountability } \\
\hline High vs. low human development (HD) & -0.29 & & 0.56 & 0.75 \\
\hline High vs. low budget transparency (BT) & -2.04 & $t *$ & 0.56 & 0.13 \\
\hline $\mathrm{HD} \times \mathrm{BT}$ & 1.47 & & 1.13 & 4.36 \\
\hline
\end{tabular}

Rule of law. Human development did not moderate the relationship between budget transparency and RL scores, $B=$ $.63, p=.524$, nor did it have a main effect on RL scores, $B=-.89, p=.072$.

Regulatory quality. Human development did not moderate the relationship between budget transparency and RQ scores, $B=-.87, p=.450$, but it did have a main effect on $\mathrm{RQ}$ scores, $B=-2.04, p=.001$. In comparison to countries that were highly transparent, the likelihood that countries that were not as transparent would have higher RQ scores dropped by .09 .

Voice and accountability. Human development did not moderate the relationship between budget transparency and VA scores, $B=1.47, p=.192$, nor did it have a main effect on VA scores, $B=-.29, p=.603$. 


\subsection{Results for 2010}

Control of corruption. The findings in Table 7 indicate that human development did not moderate the relationship between budget transparency and CC scores in 2010, B $=.87, p=.425$. Rather, human development had a main effect on CC scores, $B=-1.53, p=.005$. In comparison to countries that were highly transparent, the likelihood that countries that were not as transparent would have higher CC scores dropped by 22 .

Government effectiveness. Likewise, human development did not moderate the relationship between budget transparency and GE scores, $B=-.82, p=.501$, but it did have a main effect on GE scores, $B=-2.37, p=.001$. In comparison to countries that were highly transparent, the likelihood that countries that were not as transparent would have higher GE scores dropped by 09 .

Political stability. Human development also did not moderate the relationship between budget transparency and PS scores, $B=1.44, p=.144$, nor did it have a main effect on PS scores, $B=-.72, p=.144$.

Table 7: Logistic Regression Results for Good Governance in 2010 ( $N=73)$

\begin{tabular}{|c|c|c|c|c|}
\hline \multirow{2}{*}{$\begin{array}{l}\text { Variables } \\
\text { Control of corruption }\end{array}$} & \multicolumn{2}{|l|}{ B } & \multirow[t]{2}{*}{$S E$} & \multirow[t]{2}{*}{$O R$} \\
\hline & & & & \\
\hline High vs. low human development (HD) & -1.53 & *t* & 0.54 & 0.22 \\
\hline High vs. low budget transparency (BT) & -1.41 & 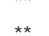 & 0.54 & 0.24 \\
\hline $\mathrm{HD} \times \mathrm{BT}$ & 0.87 & & 1.08 & 2.38 \\
\hline \multicolumn{5}{|l|}{ Government effectiveness } \\
\hline High vs. low human development (HD) & -2.37 & 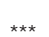 & 0.61 & 0.09 \\
\hline High vs. low budget transparency (BT) & -1.67 & 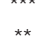 & 0.61 & 0.19 \\
\hline $\mathrm{HD} \times \mathrm{BT}$ & -0.82 & & 1.22 & 0.44 \\
\hline \multicolumn{5}{|l|}{ Political stability } \\
\hline High vs. low human development (HD) & -0.72 & & 0.49 & 0.49 \\
\hline High vs. low budget transparency (BT) & 0.16 & & 0.49 & 1.17 \\
\hline $\mathrm{HD} \times \mathrm{BT}$ & 1.44 & & 0.98 & 4.20 \\
\hline \multicolumn{5}{|l|}{ Rule of law } \\
\hline High vs. low human development (HD) & -1.09 & * & 0.50 & 0.34 \\
\hline High vs. low budget transparency (BT) & -0.74 & & 0.50 & 0.48 \\
\hline $\mathrm{HD} \times \mathrm{BT}$ & 0.49 & & 1.00 & 1.63 \\
\hline \multicolumn{5}{|l|}{ Regulatory quality } \\
\hline High vs. low human development (HD) & -2.05 & & 0.59 & 0.13 \\
\hline High vs. low budget transparency (BT) & -1.64 & 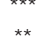 & 0.59 & 0.19 \\
\hline $\mathrm{HD} \times \mathrm{BT}$ & 0.75 & & 1.18 & 2.11 \\
\hline \multicolumn{5}{|l|}{ Voice and accountability } \\
\hline High vs. low human development (HD) & -1.99 & & 0.74 & 0.14 \\
\hline High vs. low budget transparency (BT) & -3.26 & *夫夫 & 0.74 & 0.04 \\
\hline $\mathrm{HD} \times \mathrm{BT}$ & -0.08 & & 1.48 & 0.92 \\
\hline
\end{tabular}

Rule of law. Human development did not moderate the relationship between budget transparency and RL scores, $B=$ $.49, p=.623$, but it did have a main effect on $\mathrm{RL}$ scores, $B=-1.09, p=.029$. In comparison to countries that were highly transparent, the likelihood that countries that were not as transparent would have higher RL scores dropped by .34.

Regulatory quality. Human development did not moderate the relationship between budget transparency and RQ scores, $B=.75, p=.527$, but it did have a main effect on $R Q$ scores, $B=-2.05, p=.001$. In comparison to countries that were highly transparent, the likelihood that countries that were not as transparent would have higher RQ scores dropped by .13.

Voice and accountability. Human development did not moderate the relationship between budget transparency and VA scores, $B=-.08, p=.956$, but it did have a main effect on VA scores, $B=-1.99, p=.007$. In comparison to countries that were highly transparent, the likelihood that countries that were not as transparent would have higher VA scores dropped by .14. 


\subsection{Results for 2012}

Control of corruption. As shown in Table 8, human development did not moderate the relationship between budget transparency and CC scores, $\mathrm{B}=1.87, p=.178$, nor did it have a main effect on CC scores, $\mathrm{B}=-1.12, p=.108$.

Government effectiveness. Human development significantly moderated the relationship between budget transparency and GE scores, $B=3.47, p=.048$. Post-hoc procedures reveal that within countries scoring highly on human development, there was a relationship between budget transparency and GE scores, B = -4.09, $p=.008$; in particular, in comparison to countries that were highly transparent, the likelihood that countries that were not as transparent would have higher GE scores dropped by .02. However, within countries scoring lower on human development, there was no relationship between budget transparency and GE scores.

Political stability. Despite increasing the number of iterations to 50 , a final solution could not be found. Crosstabulations revealed that there were no countries that could be categorized as high on human development with minimal budget transparency and high PS scores. It is thus possible that the result is an indication of failure of estimation.

Rule of law. Human development did not moderate the relationship between budget transparency and RL scores, $B=1.82, p=.222$. Human development also did not have a main effect on $\mathrm{RL}$ scores, $B=-.37, p=.619$.

Table 8: Logistic Regression Results for Good Governance in 2012 ( $N=53)$

\begin{tabular}{|c|c|c|c|c|}
\hline Variables & $\mathrm{B}$ & & $S E$ & $O R$ \\
\hline \multicolumn{5}{|l|}{ Control of corruption } \\
\hline High vs. low human development (HD) & -1.12 & & 0.70 & 0.33 \\
\hline High vs. low budget transparency (BT) & -0.51 & & 0.70 & 0.60 \\
\hline $\mathrm{HD} \times \mathrm{BT}$ & 1.87 & & 1.39 & 6.49 \\
\hline \multicolumn{5}{|l|}{ Government effectiveness } \\
\hline High vs. low human development (HD) & -1.62 & & 0.88 & 0.20 \\
\hline High vs. low budget transparency (BT) & -2.36 & ** & 0.88 & 0.09 \\
\hline $\mathrm{HD} \times \mathrm{BT}$ & 3.47 & ** & 1.76 & 32.14 \\
\hline \multicolumn{5}{|l|}{ Rule of law } \\
\hline High vs. low human development (HD) & -0.37 & & 0.75 & 0.69 \\
\hline High vs. low budget transparency (BT) & -1.35 & & .750 & 0.26 \\
\hline $\mathrm{HD} \times \mathrm{BT}$ & 1.82 & & 1.49 & 6.17 \\
\hline \multicolumn{5}{|l|}{ Regulatory quality } \\
\hline High vs. low human development (HD) & -1.27 & & 0.83 & 0.28 \\
\hline High vs. low budget transparency (BT) & -2.49 & 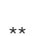 & 0.83 & 0.08 \\
\hline HD x BT & 1.73 & & 1.65 & 5.63 \\
\hline \multicolumn{5}{|l|}{ Voice and accountability } \\
\hline High vs. low human development (HD) & -1.32 & & 0.88 & .270 \\
\hline High vs. low budget transparency (BT) & -2.78 & * & 0.88 & .060 \\
\hline $\mathrm{HD} \times \mathrm{BT}$ & 0.23 & & 1.75 & 1.26 \\
\hline
\end{tabular}

Regulatory quality. Human development did not moderate the relationship between budget transparency and RQ scores, $B=1.73, p=.296$, nor did it have a main effect on RQ scores, $B=-1.27, p=.125$.

Voice and accountability. Human development did not moderate the relationship between budget transparency and VA scores, $B=.23, p=.895$, nor did it have a main effect on VA scores, $B=-1.32, p=.132$.

\section{Discussion}

In regard to the research question of whether there was a relationship between budget transparency and good governance, the answer found in this study is yes. Budget transparency was positively associated with increased levels of governance indicators in 2006 and 2008. In 2010 and 2012, OBI was related to all indicators except political stability. This result confirms the influence of budget transparency in the adoption of good governance practices by governments and increased quality of governance.

Conversely, while the result of the analysis shows the importance of budget transparency in improving quality of governance, the analysis concludes that, while the human development level of nations has an influence in shaping the relationship between budget transparency and quality of governance, this influence is not entirely significant. Thus, 
regarding the second research question of whether the relationship between budget transparency and good governance varies across levels of human development of nations, the answer varies across variables and years. While human development significantly moderated the relationship between budget transparency and regularity quality in 2006 and the relationship between budget transparency and government effectiveness in 2012, it did not moderate relationships in any other years.

To conclude, while the result emphasizes the importance of budget transparency in improving institutional quality, human development has minimal influence on the relationship between budget transparency and good governance. The length and complexity of the public budget makes it difficult for the average citizen to understand, and this could be a reason for the minimal influence of human development on the relationship. Also, the result confirms a significant influence of human development on the relationship between budget transparency on one hand and regulatory quality and government effectiveness on the other, which can be interpreted in terms of people devoting more attention to those factors that have a direct influence on their daily lives (e.g., regulatory quality and government effectiveness) than to the rest of the factors.

Furthermore, other factors that might maximize the influence of public budget transparency on institutional quality (e.g., political and social factors) have not been included in the analysis. Also, the current study covers only four years, whereas including more years in the analysis might give us better understanding of the effect of the human development level of nations on the relationship between budget transparency and quality of governance.

\section{References}

Acosta, A. (2013). The Impact and Effectiveness of Accountability and Transparency Initiatives: The Governance of Natural Resources. Development Policy Review, 31 (S1), p.s89-s105

Adams, S., \& Mengistu, B. (2008). Privatization, Governance and Economic Development in Developing Countries. Journal of Developing Societies, 24(4), 415-438.

Alkire, S. (2010). Human Development: Definitions, Critiques, and Related Concepts. Human Development Reports (Research Paper 2010/01). Retrieved 06-20-2011 from http://hdr.undp.org/en/reports/global/hdr2010/papers/HDRP_2010_01.pdf.

Arndt, C., and Oman, C. (2006). Uses and Abuses of Governance Indicators. Paris, France: Development Centre Studies, OECD Publishing. Retrieved 06-20-2010 from http://www.worldbank.org/ieg/governance/oman_arndt_paper.pdf.

Benito, B. and Bastida, F. (2009). Budget transparency, fiscal performance, and political turnout: An international approach. Public Administration Review, 69(3), p.403-417.

Carlitz, R. Renzio, P. Krafchik, W. Ramkumar, V. (2009). Budget transparency around the world: Results from the 2008 open budget survey. OECD Journal on Budgeting, 82 (2), 81-97.

de Ferranti, D., Jacinto, J., Ody, A., \& Ramshaw, G. (2009). How to Improve Governance: A New Framework for Analysis and Action. Washington, D.C: Brookings Institution Press.

de Renzio, P., Gomez, P., \& Sheppard, J. (2005). Budget transparency and development in resource-dependent countries. International Social Science Journal, 57(s1), 57-69.

Denhardt, J., Denhardt, R. (2007). The New Public Service: Serving, not Steering. Armonk, NY: M.E. Sharpe.

Gaventa, J. and McGee, R. (2013). The Impact of Transparency and Accountability Initiatives. Development Policy Review, 31(s1), s3s28.

Grindle, M. (2010). Good Governance: The Inflation of an Idea. (HKS Faculty Research Working Paper Series -Research Paper: RWP10-023), John F. Kennedy School of Government, Harvard University. Retrieved 10-09-2011 from http://dash.harvard.edu/ bitstream/handle/1/4448993/Grindle_GoodGovernance.pdf?sequence=1

Hameed, F. (2011). Budget Transparency and Financial Markets. International Budget Partnership (IBP Working Paper No. 1). Washington, D.C., USA. Retrieved 2/1/2015 from http://www.internationalbudget.org/wp-content/uploads//BP-Working-Paper-1Budget-Transparency-and-Financial-Markets.pdf

Haq, M. (1995). Reflections on Human Development. New York, NY: Oxford: Oxford University Press.

Hira, A., \& Hira, R. (2000). The New Institutionalism: Contradictory Notions of Change. American Journal of Economics and Sociology, 59 (2), 267-282.

International Budget Partnership. (2012). Open Budget Survey 2012. Retrieved 12/1/2014 from http://internationalbudget.org/wpcontent/uploads/OBI2012-Report-English.pdf.

Kaufmann, D., \& Kraay, A. (2002). Growth without Governance [with Comments]. Economía, 3(1), 169-229.

Kaufmann, D., Kraay, A., and Mastruzzi, M. (2009). Governance Matters VIII: Aggregate and Individual Governance Indicators 19962008 (Policy Research Working Paper, No. 4978). Washington, DC: World Bank. Retrieved 4-21-2010 from http://unpan1.un.org/ intradoc/groups/public/documents/un-dpadm/unpan039285.pdf.

Kaufmann, D., Kraay, A., \& Mastruzzi, M. (2010). The Worldwide Governance Indicators: Methodology and Analytical Issues (World Bank Policy Research Working Paper No. 5430). Washington, DC: The World Bank.

Kolstad, I. and Wiig, A. (2009). Is Transparency the Key to Reducing Corruption in Resource-Rich Countries? World Development, $37(3), 521-532$. 
Kosack, S., and Fung, A. (2014). Does Transparency Improve Governance? The Annual Review of Political Science, 17, 65-87.

Langbein, L., and Knack, S. (2010). The Worldwide Governance Indicators: Six, One, or None? Journal of Development Studies; 46(2), 350-370.

Lindstedt, C., and Naurin, D. (2010). Transparency is not Enough: Making Transparency Effective in Reducing Corruption. International Political Science Review, 31(3), 301-322.

Masud, H. (2011). Is there hope for budget transparency? Findings from the Open Budget Survey 2010. International Journal of Government Financial Management, 11(1), 43-52.

McGillivray, M. (1991). The Human Development Index: Yet Another Redundant Composite Development Indicator? World Development, 19(10), 1461-1468.

Mimicopoulos, M., Kyj, L., and Sormani, N. (2007). Public Governance Indicators: a Literature Review. New York, NY: United Nations publications.

Ndulu, B., \& O'Connell, S. (1999). Governance and Growth in Sub-Saharan Africa. The Journal of Economic Perspectives, 13(3), pp. 4166.

Noorbakhsh, F. (1998). The human development index: some technical issues and alternative indices. Journal of International Development, 10(5): 589-605.

Persson, A, Rothstein, B. and Teorell, J. (2010). The Failure of Anti-Corruption Policies: A Theoretical Mischaracterization of the Problem. QoG Working Paper Series 2010:19. Gothenburg: University of Gothenburg.

Pradhan, R. \& Sanyal, G. (2011). Good Governance and Human Development: Evidence form Indian States. Journal of Social and Development Science, 1 (1), pp. 1-8.

Ranis, G., Stewart, F., \& Samman, E. (2006). Human Development: Beyond the Human Development Index. Journal of Human Development, 7(3), 323-358.

Riddell, R. (2007). Does Foreign Aid Really Work? New York, NY: Oxford University Press.

Sagar A., \& Najam, A. (1998). The Human Development Index: a Critical Review. Ecological Economics, 25(3), pp. 249-264.

Santiso, C. (2006). Improving fiscal governance and curbing corruption: how relevant are autonomous audit agencies? International Public Management Review, 7(2), 97-108.

Santiso, C. (2001). Good Governance and Aid Effectiveness: The World Bank and Conditionality. The Georgetown Public Policy Review, $7(1), 1-22$.

Shah, A. (Ed.). (2007). Budgeting and Budgetary Institutions. World Bank Publications: Washington, D.C., USA.

Smith, B. (2007). Good Governance and Development. New York, NY: Palgrave Macmillan.

Stiglitz, J. (2002). On Liberty, the Right to Know and Public Discourse: The Role of Transparency in Public Life. In M. Gibney (Ed.), Globalizing rights. Oxford: Oxford University Press.

Streeten, P. (1994). Human Development: Means and Ends. American Economic Review, 84(2), 232-237.

The Organization for Economic Co-operation and Development (OECD). (2002). OECD Best Practices for Budget Transparency. Retrieved 15/11/2014 from http://www.oecd.org/governance/budgeting/Best\%20Practices\%20Budget\%20Transparency\%20\%20complete\%20with\%20cover\%20page.pdf

Thomas, M. (2008). What do the worldwide governance indicators measure? Retrieved 4/20/10 from http://www.sais-jhu.edu/bin/q/rl What $\% 20$ Do\%20the\%20 Worldwide\%20 Governance\%20 Indicators\%20Measure.pdf.

United Nations Development Program (UNDP) (2010). Human Development Report 2010 20th Anniversary Edition. The Real Wealth of Nations: Pathways to Human Development. (2nd ed.). New York, NY: Palgrave Macmillan. Retrieved 06-26-2011 from http://hdr.undp.org/en/media/HDR_2010_EN_Complete_reprint.pdf.

United Nations Economic and Social Commission for Asia and the Pacific (UNESCAP). (2009). What is Governance? Retrieved 02/10/2011 from http://www.unescap.org/pdd/prs/ProjectActivities/Ongoing/gg/governance.pdf

Wehner, J., \& de Renzio, P. (2013). Citizens, Legislators, and Executive Disclosure: The Political Determinants of Fiscal Transparency. World Development, 41(C), 96-108.

Wildavsky, A. (1961). Political implications of budgetary reform. Public Administration Review, 21(4), p.183-190.

Williamson, O. E. (1998). The Institutions of Governance. The American Economic Review, 88 (2), 75-79.

Zucolotto, R., and Teixeira, M. (2014). Budgetary Transparency and Democracy: The Effectiveness of Control Institutions. International Business Research, 7(6), p83-96. 